\title{
CMA adopts new governance structure
}

\author{
The following 3 pages feature articles on an array of medical and political issues that surfaced \\ at the Canadian Medical Association's 141st General Council and annual general meeting held \\ in Montréal, Quebec, Aug.17-20, 2008.
}

An earlier version of this article was published at www.cmaj.ca on Aug. 20, 2008.

$\mathrm{T}$ he size of the Canadian Medical Association Board of Directors will be pared down from 34 to 25, while its core councils and committees will feature regional, rather than provincial, representation under governance reforms approved by delegates to CMA's General Council.

The organization will be "smaller and more nimble and able to respond to issues of concern to doctors and the public," said Dr. Louise Cloutier, chair of the CMA board of directors.

The package of reforms aimed at modernizing the association's governance structure and strengthening the role of general council was approved by an $86 \%$ majority of delegates at general council, after extensive debate and several unsuccessful attempts to disaggregate the package by hiving off some of its more controversial components.

Clouthier said solid majority support of the governance reforms "reinforced the role of general council as the legislative body."

Among the most controversial elements of the package is the move to regional representation on CMA core councils, which will be downsized.

Former CMA president Victor Dirnfeld was particularly outspoken about some changes that he characterized as a "move towards an industrial model of efficiency" that might serve to gag dissent in the association.

And delegates from smaller provinces and territories expressed concern about the move away from divisional towards regional representation on the CMA core councils, saying the result will be reduce voting membership from 15 to 8 .

"I fear, as a small province, that the risk is that our voice will be completely lost," said Dr. Lydia Hatcher, a divisional representative from Newfoundland and Labrador.

The change is of special concern to

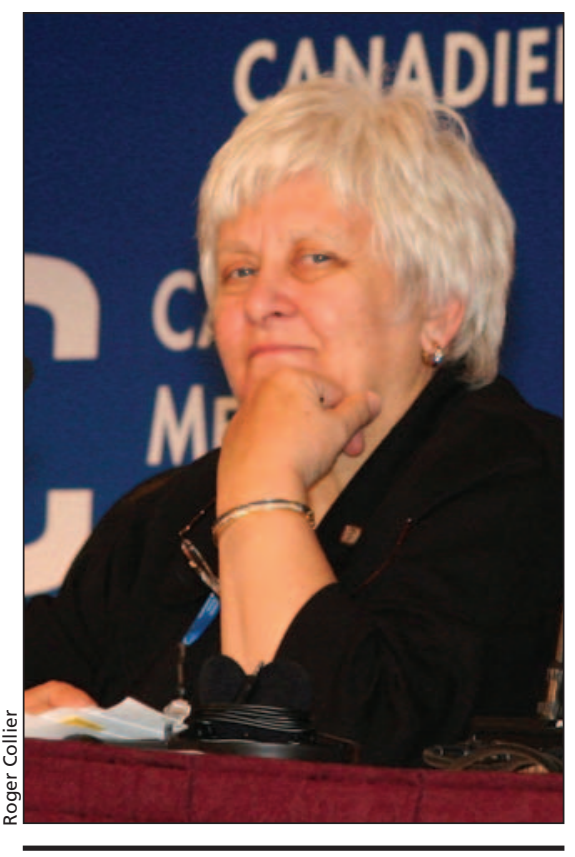

Chair of the CMA Board of Directors Dr. Louise Clouthier says governance reforms will make the association more responsive.

the Yukon, said Dr. Wayne MacNichol of Whitehorse. "The unique perspective of the North and isolated regions will be lost. I don't think all the leadership forums and e-conferences will replace" representation on core councils.

"I have yet to hear a credible reason to go from divisional to regional membership — nimbleness [of response] has never been an issue," said Dr. Guido Van Rosendaal of Calgary, chair of the CMA Council on Health Care and Promotion.

CMA board member Dr. T.K. Lee said the advantages of divisional representation on core councils could be achieved by other types of member involvement, including more spots for smaller provinces to go to leadership meetings and opportunities to serve on time limited task forces that the board of directors would establish and rely on in the revised governance structure. To that end, new monies would be available to bring doctors from provincial and territorial medical associations to the CMA Leaders' Forum.

Also contentious was a recommendation to eliminate the voting rights of some medical organizations.

Under the new governance regime, 15 Focused Medical Interest Associations - including the Canadian Association of Physicians for the Environment, the Canadian Medical Protective Association and the Federation of Medical Women of Canada - lose their voting rights at general council. These associations would be shifted to associate status, and hold only observer status at the meeting.

As well, the Committee on National Medical Organizations - which is now comprised of the Focused Medical Interest Groups, as well as the national specialty societies - would be replaced by a Specialists' Forum.

Some delegates were unenthusiastic about this move.

The focused medical interest groups "do add to the diversity of general council and we want to hear their input," said Lee.

But there has been concern about the growth in the number and influence of those groups as voting members at general council and hence a concern about the "protection of votes of federated members of the CMA," explained Dr. John Rapin, CMA honorary treasurer and executive committee member.

The bulk of the governance reforms take effect in 1 year. Those include a request that provincial and territorial medical associations allot a percentage of their general council delegates to members-at-large or select those delegates from the general membership. Ann Silversides, CMAJ

DOI:10.1503/cmaj.081323 